\title{
Effects of octopus predation on motile invertebrates in a rocky subtidal community
}

\author{
Richard F. Ambrose* \\ Department of Biology, University of California, Los Angeles, California 90024, USA
}

\begin{abstract}
Octopus bimaculatus, a common member of intertidal and subtidal communities in southern California, consumes many motile benthic invertebrate species, including snails, chitons, limpets, bivalves, and crustaceans. An analysis of octopus drill holes in empty snail shells indicates that $O$. bimaculatus is a major snail predator in the community. The addition of marked snails to a natural reef with unmanipulated octopus densities demonstrated that octopuses can quickly reduce snail abundances, consuming $24 \%$ of the available snails within $24 \mathrm{~d}$. During $5 \mathrm{yr}$ at 1 site, actopus abundance declined from 40 to 8 octopuses, while total prey abundance increased from 16 to 80 ind $\mathrm{m}^{-2}$. A second site experienced a similar drop in octopus density and increase in prey density over 3 уг. At both sites, snails and hermit crabs showed the greatest increases. Sedentary grazers, bivalves, and crabs and shrimps occurred at low densities throughout, possibly because the abundances of these preferred prey were depressed by octopus predation even during years of low octopus density. In spite of the strong negative association at the 2 sites between octopus and prey over time, for a single time period at 15 different sites prey densities were not negatively correlated with the densities of their predators. However, octopus densities were much higher when they appeared to reduce the abundances of their prey than when the 15 different sites were sampled. I conclude that octopus predation can dramatically reduce prey densities when octopuses are unusually common, but that in most years the abundance of octopuses is too low to disrupt the basic patterns of prey abundance that result from other processes. The highest prey species richness and diversity at the 2 study sites occurred during years of lowest octopus densities. Species richness, diversity and evenness of the prey assemblage were not correlated with octopus, lobster or predatory gastropod abundances at the 15 different locations; when the effects of habitat structure were held constant by partial correlation, seastar abundance was negatively correlated with species richness and diversity. The relation between predation and species diversity suggests that, when predation is effective in this assemblage, it decreases diversity.
\end{abstract}

\section{INTRODUCTION}

Predators often influence the structure of communities. The effect of predation on the number of cooccurring species in a community (Paine 1966, Harper 1969) has perhaps attracted the most attention. Underlying the effects of predators on diversity are their effects on the abundances and/or distributions of their prey. In marine communities, most studies of predation have involved sessile or sedentary organisms (Lubchenco 1978, Tribble 1981, Connell 1970, Russ 1980, and many others). Remarkably few studies have evaluated how predation affects assemblages of motile benthic species.

Motility itself may influence the nature of the pre- Present address: Department of Biological Sciences, Uni-
versity of California, Santa Barbara, California 93106, USA dator-prey interaction, since new defenses against predation are available through movement. Running responses are very common in motile benthic invertebrates (Feder 1963, Ansell 1969, Schmitt 1981, McKillup 1982). Motility also allows prey to use temporary refuges, thereby reducing exposure to predation (Hall et al. 1970, Nelson \& Vance 1979, Wells 1980, Bernstein et al. 1981, Menge \& Lubchenco 1981, Hines \& Pearse 1982). These responses may have important consequences for prey distributions and the organization of the prey assemblage (Vance 1979, Markowitz 1980, Menge \& Lubchenco 1981, Schmitt 1982, Fawcett 1984).

In spite of motility-related defenses, predation on motile species has been reported to be important in some communities. In temperate subtidal habitats, sea otters, fish, and crabs may drastically reduce the abundance of urchins (Muntz et al. 1965, Duggins 
1980, Bermstein et al. 1981) and abalone (Hines \& Pearse 1982). Slower-moving predators such as seastars may affect gastropod (Paine 1969. Schmitt 1982) and urchin (Bernstein et al. 1981) distributions and abundances.

Octopuses have been reported to be major predators of motile species in several marine communities (Onuf 1972, Fotheringham 1974, Wells 1980, Schmitt 1982, Ambrose \& Nelson 1983, Fawcett 1984). From 1978 to 1982. I examined the interactions between Octopus bimaculatus Verrill, a common member of intertidal and subtidal communities in southern California, and its prey, assorted motile benthic invertebrates on subtidal rocky substrates. My intent was to determine the impact of octopus predation on prey species abundances and species richness. In this paper, I examine first the importance of octopus predation, relative to other predators, using field observations and experiments. To evaluate the impact of octopus predation. on the abundances of its prey, I monitored octopus abundance and prey densities at a single location for 5 yr. For 3 of the 5 yr I also made observations on octopus and prey densities at a second location. Finally, I test the expectation that, if predators are a significant mortality source for their prey, prey abundances will be negatively correlated to predator abundances by relating the abundances of octopuses and other predators to prey abundances and the compostition of the prey assemblage at different locations at Santa Catalina Island.

\section{Natural history of Octopus bimaculatus}

The two-spotted octopus Octopus bimaculatus occurs from Santa Barbara, California and the Channel Islands to the southern tip of Baja California and in the Gulf of California (Hochberg \& Fields 1980). O. bimaculatus is found in holes and crevices in a wide range of hard-substrate habitats. Although shelters may be scarce in some areas, it appears that shelters generally do not limit the size of $O$. bimaculatus populations (Ambrose 1982a). Many octopuses inhabit the same shelter for an extended period of time (at least $1 \mathrm{mo}$; Ambrose 1982a). Mating occurs year-round, but peaks in winter. Females brood their eggs for 1 to 3 mo in late spring through early summer and die soon after the eggs hatch. The young are planktonic for one to several months before settling to the bottom. In spite of nearly synchronous hatching at Santa Catalina Island, young $O$. bimaculatus settle throughout the year. After settlement, juveniles live in small shelters and kelp holdfasts, and apparently feed primarily on small crustaceans. The lifespan of $O$. bimaculatus is probably 12 to $18 \mathrm{mo}$, depending on the time of settlement.
Octopus bimaculatus is a generalist predator that consumes a wide variety of motile benthic invertebrates; at Santa Catalina Island, snails make up $75 \%$ of its diet, with chitons, bivalves, crabs, and hermit crabs comprising most of the remaining portion (Ambrose 1984). Invertebrate predators that cooccur with $O$. bimaculatus and consume the same prey, plus some sessile species, include the seastar Pisaster giganteus, the lobster Panulirus interruptus, and the snail Kelletia kelletii. This assemblage of predators and prey species has previously been studied by Schmitt (1982), who described species abundance patterns over a variety of rocky substrates, including cobble areas.

\section{METHODS}

I examined 15 locations on the lee side of Santa Catalina Island, off the coast of California, USA $\left(33^{\circ} 27^{\prime} \mathrm{N}, 118^{\circ} 29^{\prime} \mathrm{W}\right.$; Fig. 1). The 15 locations include many substrate and vegetation types, but all are relatively protected horizontal areas in less than $10 \mathrm{~m}$ of water. The most common substrates are small rocks, boulders and bedrock, sometimes interspersed with sand and shelly debris; because few predators occur in cobble areas (Schmitt 1982, pers. obs.), I have not included this habitat. Vegetation on these rocky substrates characteristically consists of 'bushy' algae and erect and encrusting coralline algae. Most rocky reefs support forests of giant kelp Macrocystis pyrifera; Eisenia arborea is locally abundant at shallow (3 to $5 \mathrm{~m}$ ) depths. At some locations an introduced species, Sargassum muticum, achieves extremely high densities in winter (Ambrose \& Nelson 1982). The sites are described in more detail in Ambrose (1982b).

A permanent study site was established at the east end of Bird Rock ('East Bird Rock'), an islet $0.5 \mathrm{~km}$ off Santa Catalina Island (Fig. 1, Site \#14). Since 1976, giant kelp has been nearly absent and Sargassum muticum has been seasonally very abundant. The study site depth varied from $4 \mathrm{~m}$ (at the lower edge of an Eisenia arborea bed) to a maximum of $10 \mathrm{~m}$. East Bird Rock was chosen because it supported a large octopus population. Lobsters were also active on the site, although they concentrated their foraging activities in a nearby intertidal mussel bed. Seastars and Kelletia kelletii, though present, were never numerous.

Shell censuses. Octopuses typically kill their shelled prey by drilling a small hole in the shell to inject poison (Pilson \& Taylor 1961). Octopus drill holes have a characteristic shape and can easily be distinguished from the drill holes of predatory gastropods. It is possible to obtain a rough estimate of octopus predation 
Fig. 1. Location of the 15 study sites on the northwest shore of Santa Catalina Island. Sites, numbered in order of increasing octopus density, are: 1 , Middle Bird Rock, 2, Chalk Cliffs, 3, Intake Pipes, 4, West Emerald Bay, 5, East Big Fisherman, 6, West Arrow Point, 7, Lion's Head, 8, Ship Rock, 9, Isthmus Reef, 10, Habitat Reef, 11, Black Can, 12, West Bird Rock, 13, Pumpernickel Cove, 14, East Bird Rock, 15, Cherry/Fourth of July. Location of Catalina Marine Science Center (CMSC) is also indicated

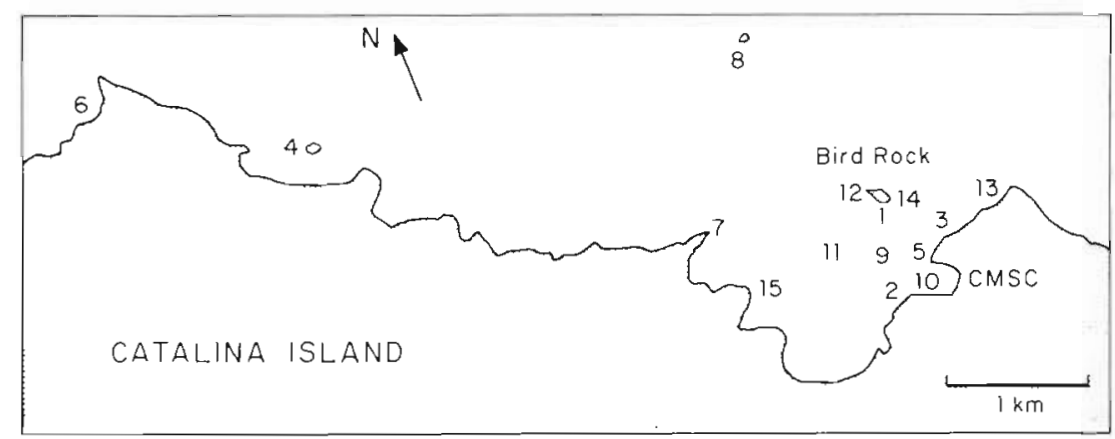

by censusing empty shells in the field to determine the proportion drilled by octopuses (Fotheringham 1974, Ambrose \& Nelson 1983, Fawcett 1984).

Field experiment at Isthmus Reef. To estimate the mortality rate of snails under conditions of unmanipulated octopus density, marked snails were added to a relatively isolated rocky reef at Isthmus Reef (Fig. 1, Site \#11) in November 1977. Reef area was approximately $75 \mathrm{~m}^{2}$. Natural snail abundance was extremely low: only 1 Astraea undosa was found on the reef. One hundred marked individuals of each of 3 snail species, Tegula aureotincta, T. eiseni, and Norrisia norrisi, were placed on the reef. Snails were marked in the laboratory by applying ink to the top of the shell. After the snails were added, prey densities were within normal densities observed in similar habitats. Asteroid and octopus densities were monitored by visual census of the reef (but not manipulated) and all newly killed snails (i.e. empty shells), both marked and unmarked, were collected on 7 occasions during $24 \mathrm{~d}$. After $24 \mathrm{~d}$, all remaining marked snails were collected. A few days after placement, some marked $T$. aureotincta and $N$. norrisi were found to have emigrated from the reef, so fewer of these species were available to the predators. Therefore, mortality of the marked population was based only on snails actually available to the predators (i.e. still on the reef), estimated as the total number of marked snails (alive and dead) collected from the reef.

Temporal comparison. East Bird Rock was censused for octopuses on 68 occasions between June 1976 and July 1982. During each census all known and potential octopus shelters were examined and the location of each octopus recorded. The octopus population during these varied from 7 to 45 octopuses (mean $\pm \mathrm{SD}=23.2$ \pm 11.5 ). These fluctuations make it possible to relate prey densities to the size of the octopus population. I measured prey densities at East Bird Rock (as described below under 'Abundance patterns') at yearly intervals from 1978 until 1982 (October 1978, June 1979, June 1980, July 1981, July 1982). Because both predator and prey abundances were measured at the same time and in the same place for many years, these data should indicate whether octopuses had an impact on their prey.

Octopus and prey densities were also measured at West Bird Rock (Site \#12). This site is similar to the East Bird Rock site in depth and topography, but supports a dense giant kelp forest; Sargassum muticum has not yet achieved high abundances. Species abundances were measured at West Bird Rock in 1979, 1980, and 1981. Octopus densities were measured as described below rather than censused as at East Bird Rock.

Abundance patterns. Species densities were measured at 15 different locations on the lee side of Catalina (Fig. 1). To reduce the effects of seasonal and yearly variation in predation, all sampling was completed during a short period of time (16 Jun to $23 \mathrm{Jul}$ 1980). Sampling was restricted to a single habitat type: shallow rocky substrates. Predators were sampled in a large area (approximately $200 \mathrm{~m}^{2}$ ) because they are large and motile.

At each study site, predator density was measured by searching systematically for $0.5 \mathrm{~h}$ on one side of a $20 \mathrm{~m}$ line. The numbers of Octopus bimaculatus, Pisaster giganteus, Panulirus interruptus, and Kelletia kelletii were recorded, and the area searched was measured for calculation of the density of each predator.

Prey densities were measured by censusing 20 (22 at Site \#15) haphazardly placed $0.25 \mathrm{~m}^{2}$ quadrats. All individuals of the potential prey species were counted in each quadrat. Prey were classified into 7 groups on the basis of ecological, morphological, and/or taxonomic criteria, as follows: (1) snails; (2) sedentary grazers, including limpets, chitons, and abalone; (3) unattached bivalves; (4) crustaceans, including crabs and shrimps; (5) hermit crabs; (6) vermetid gastropods (sessile snails); and (7) sessile prey, such as attached bivalves and bamacles. These groups encompass most of the large species on subtidal rocky substrates at Catalina; not included were sea cucumbers, urchins, less conspicuous taxa such as polychaete worms, and rare or small-bodied taxa such as nudibranchs. 
Individuals were identified to the species level, with the following exceptions. Because of their rapid movements, some shrimps and crabs could not be identified. Chitons, limpets, and abalone were not identified to the species level; usually no more than one species from each of these groups occurred at any given site. Hermit crabs were also not identified to the species level; because more than one hermit crab species may have occurred at some sites, the number of hermit crab species in this analysis may be slightly underestimated.

The diversity of the prey species assemblage was estimated by the Shannon-Weiner diversity index, calculated as $\mathrm{H}^{\prime}=-\Sigma p_{\mathrm{i}} \ln p_{\mathrm{i}}$, where $p_{1}$ refers to the fraction of all prey individuals belonging to the $i$ th species. Evenness was estimated as EV $=\mathrm{H}^{\prime} / \ln s$, where $s$ is the number of species in the sample (Pielou 1977).

Since structural differences among the study sites could confound the relations between predators and prey, substrate type and heterogeneity were measured at 14 of the sites. Principal Components Analysis (PCA) was performed to reduce the number of variables and eliminate the confounding effects of intercorrelations. PCA reduces the dimensionality of a set of variables with as little loss of information as possible by producing new 'variables' (components) that are linear combinations of the original variables and are uncorrelated with one another. A PCA of the habitat structure data yielded 2 components that together accounted for over $80 \%$ of the total variance of the original data. The first principal component (PC1) represents the structural complexity of the habitat, while the second (PC2) represents rocks less than $10 \mathrm{~cm}$ in diameter (see Ambrose $1982 \mathrm{~b}$ for further details).

Relations between predator and mean prey abundances for the 15 sites were examined using productmoment correlation coefficients. Partial correlations, holding the habitat PC1 and PC2 constant, were calculated for the 14 sites for which habitat data were available. Calculation of correlation coefficients for all possible pairs of variables resulted in large matrices of coefficients. Because of the Type I error accepted when testing the significance of these coefficients, the meaning of 'significance' is not always clear; for example, with 100 coefficients, 5 are expected to indicate a 'significant' relation by chance alone at the 0.05 probability level. To evaluate the overall significance pattern for each matrix, the confidence limits of the observed percentages of significant correlations were compared to that expected by chance alone (Rohif \& Sokal 1969, 208). Multivariate analyses were performed using the BMDP Biomedical Computer programs (Dixon \& Brown 1979).

\section{RESULTS}

\section{Shell censuses}

Empty shells were censused in the field to indicate the magnitude of octopus predation relative to other sources of mortality. The percentage of empty snail shells with octopus drill holes ranged from $14 \%$ for Tegula eiseni to $69 \%$ for Norrisia norrisi (Table 1 ). These data reflect only non-lobster mortality sources because lobsters crush shells before eating them, and only whole shells could be censused accurately.

Drilled shells may not represent the actual number of individuals eaten by Octopus bimaculatus because octopuses do not necessarily drill all snails they consume. Table 1 gives 3 independent estimates of the proportion of snails that were eaten by octopuses but not drilled. With the exception of Tegula eiseni at Pumpernickel Cove, the 3 data sets are very similar in spite of different collection conditions (laboratory preference experiments, a field experiment, and natural field conditions).

Octopuses may also drill a snail without eating it. However, examination of live individuals in the field showed that, except for Norrisia norrisi, this event rarely occurred (Table 1). Approximately $16 \%$ of the live $N$. norrisi censused had been drilled at least once by octopuses. (Some drill holes may have been covered by barnacles [Schmitt et al. 1983], but these would not bias the census because they also affect the drilled category.)

Adjusting the proportion of shells that were drilled by taking into account the snails that were eaten but not drilled, and drilled but not eaten, I estimate that octopuses caused between $57 \%$ and $99 \%$ of the mortality experienced by the snails censused.

The shell censuses do not consider mortality due to lobsters. During the Isthmus Reef experiment, octopuses caused 6 times more mortality than lobsters. A similar experiment on a cobble reef at Pumpernickel Cove (near Site \#13), where lobsters apparently were more abundant, resulted in a rapid decimation of the Norrisia norrisi population by lobsters; lobsters accounted for $84 \%$ of the $N$. norrisi mortality while octopuses caused $16 \%$ (unpubl. data). But for the other snails in this experiment, lobsters caused no known mortality. I infer that for some species, and perhaps at some sites, lobsters may occasionally be potent mortality sources, but they generally have much less impact. Since lobsters consistently consume some of the same snail species as octopuses, estimates of mortality due to octopuses based on shell censuses alone are probably somewhat high. Nonetheless, these data demonstrate that octopuses are a major mortality source for their prey. 
Table 1. Natural snail mortality due to octopuses. Percentage of whole shells drilled was determined by field censuses. Percentages of snails eaten but not drilled (No. eaten but not drilled/total no. eaten) were determined by: (a) laboratory data; (b) mortality during an experiment at Pumpernickel Cove (near Site \#13), in which 100 marked snails each of Tegula eiseni, T. aureotincta and Norisia norrisi were added to a cobble area with an unmanipulated octopus population and no seastars or Kelletia kelletii; and (c) prey discards recorded at East Bird Rock between Sep and Nov 1978. An overall average was used to adjust the shell census data (e.g. $37 / 73=50.7 \%$ of $T$. eiseni were eaten but not drilled). The estimate of the percent mortality due to octopuses was obtained by adding the percent drilled to the percent eaten but not drilled (average) and subtracting the percent drilled but not eaten. $\mathrm{N}=$ total number of shells, $\mathrm{TE}=T$. eiseni, $\mathrm{TA}=T$. aureotincta, $\mathrm{AU}=$ Astraea undosa and $\mathrm{NN}=N$. norrisi

\begin{tabular}{|c|c|c|c|c|c|c|c|c|}
\hline \multirow[t]{2}{*}{ Category } & \multicolumn{2}{|c|}{ TE } & \multicolumn{2}{|c|}{ TA } & \multicolumn{2}{|c|}{$A U$} & \multicolumn{2}{|c|}{ NN } \\
\hline & $N$ & $\%$ & $N$ & $\%$ & $N$ & $\%$ & $N$ & $\%$ \\
\hline Drilled & 209 & 14.4 & 75 & 45.3 & 41 & 58.5 & 172 & 69.2 \\
\hline \multicolumn{9}{|l|}{ Eaten but not drilled } \\
\hline Laboratory & 21 & 38.1 & 205 & 11.2 & 34 & 44.1 & 57 & 22.8 \\
\hline $\begin{array}{l}\text { Pumpernickel } \\
\text { Cove experiment }\end{array}$ & 21 & 81.0 & 14 & 14.3 & - & - & 24 & 20.8 \\
\hline $\begin{array}{l}\text { Bird Rock prey } \\
\text { discards }\end{array}$ & 31 & 38.7 & 120 & 11.7 & 7 & 28.6 & 13 & 27.8 \\
\hline Average & 73 & 50.7 & 339 & 11.5 & 41 & 41.5 & 94 & 23.0 \\
\hline Drilled but not eaten & 176 & 0.0 & 34 & 0.0 & 126 & 0.8 & 123 & 16.3 \\
\hline $\begin{array}{l}\text { Estimated \% mortality } \\
\text { due to octopuses }\end{array}$ & & 65.1 & & 56.8 & & 99.2 & & 75.9 \\
\hline
\end{tabular}

\section{Field experiment at Isthmus Reef}

To determine the rate at which natural octopus populations can eliminate their prey, marked snails were added to an isolated rocky reef at Isthmus Reef. Octopus density, which was not manipulated, varied from 4.0 to 6.7 octopuses $100 \mathrm{~m}^{-2}$ during the experiment.

Within $24 \mathrm{~d}$, octopuses consumed 21 to $26 \%$ of the available snails (Table 2). Octopuses accounted for approximately the same amount of the mortality for all 3 snail species. However, because emigration from the reef reduced the availability of Tegula aureotincta and Norrisia norrisi, all predators ate fewer individuals of these species (16 and 12, respectively) than $T$. eiseni (42). Octopuses ate 1.5 snails per day, with $T$. eiseni comprising nearly half of those eaten. These estimates are conservative because some of the undrilled snails were probably eaten by octopuses. Adjusted data, using the averages from Table 1 , suggest that octo-

Table 2. Mortality during Isthmus Reef experiment. One hundred marked snails of each species were placed on the $75 \mathrm{~m}^{2} \mathrm{Ieef}$. All empty shells, both marked and unmarked, were collected on 7 occasions during the $24 \mathrm{~d}$ observation period

[A] Mortality of marked snail population. The mortality due to different predators is based on the number of snails available

\begin{tabular}{|c|c|c|c|c|c|}
\hline \multirow[b]{2}{*}{ Species } & \multirow{2}{*}{$\begin{array}{l}\text { Total no. marked } \\
\text { shells recovered }\end{array}$} & \multicolumn{4}{|c|}{$\begin{array}{c}\text { Mortality source } \\
\text { (\% of total shells recovered) }\end{array}$} \\
\hline & & Drilled & Not drilled & Lobster & Total \\
\hline Tegula eiseni & 71 & $21.1 \%$ & $35.2 \%$ & $2.8 \%$ & $59.2 \%$ \\
\hline Tegula aureotincta & 31 & $25.8 \%$ & $16.1 \%$ & $9.7 \%$ & $51.6 \%$ \\
\hline Nornisia norrisi & 37 & $24.3 \%$ & $8.1 \%$ & $0.0 \%$ & $32.4 \%$ \\
\hline \multicolumn{6}{|c|}{ [B] Average number of marked and unmarked snails eaten per day } \\
\hline Species & & Drilled & Not drilled & Lobster & Total \\
\hline Tegula eiseni & & 0.73 & 1.18 & 0.18 & 2.09 \\
\hline Tegula aureotincta & & 0.36 & 0.23 & 0.23 & 0.82 \\
\hline Norrisia norrisi & & 0.41 & 0.14 & 0.14 & 0.68 \\
\hline
\end{tabular}


puses consumed $39 \%$ of the $T$. eiseni, $28 \%$ of the $T$. aureotincta, and $26 \%$ of the $N$. norrisi.

Two other predators, Pisaster giganteus and Panulirus interruptus, were also active on the reef, and in $24 \mathrm{~d}$ all 3 combined killed nearly $50 \%$ of the available snails.

\section{Temporal comparison}

Octopus abundance at East Bird Rock decreased from 40 in 1978 to 8 in 1982, while total prey densities increased steadily from $4.1 \pm 0.8$ to $19.6 \pm 1.5$ ind $0.25 \mathrm{~m}^{-2}$ (mean \pm SE; Fig. 2). Octopus abundance was negatively correlated with total prey abundance $(\mathrm{r}=$ $-0.89, p<0.05$ ) and snail abundance $(r=-0.90$, $p<0.05)$. Prey group abundances were significantly different among years (2-way ANOVA, $p<0.001$; Table 3A). Snails showed the most dramatic abundance change, increasing nearly 5 -fold over the $5 \mathrm{yr}$
Table 3. Summary of analysis of variance for yearly prey group abundances at Bird Rock. $\cdots$ indicates $p<0.001$

$\begin{array}{lll}\text { Sum of } & \text { Mean } \\ \text { Squrce of variation } & \text { squares }\end{array}$ df $\quad$ square

[A] East Bird Rock (1978 - 1982)

$\begin{array}{lrrrr}\text { Prey group } & & & & \\ \text { abundance } & 6286.0 & 4 & 1571.5 & 340.3 \cdots \\ \text { Year } & 587.8 & 4 & 146.9 & 31.8 * \cdots \\ \text { Interaction } & 1860.2 & 16 & 116.3 & 25.2^{\cdots} \\ \text { Residual } & 1875.0 & 406 & 4.6 & \end{array}$

[B] West Bird Rock $(1979$ - 1981)

$\begin{array}{lrrrr}\text { Prey group } & & & & \\ \text { abundance } & 405.3 & 4 & 101.3 & 39.6^{*} \cdots \\ \text { Year } & 41.6 & 2 & 20.6 & 8.1^{*} \\ \text { Interaction } & 96.1 & 8 & 12.0 & 4.7 * \cdots \\ \text { Residual } & 576.4 & 225 & 2.6 & \end{array}$
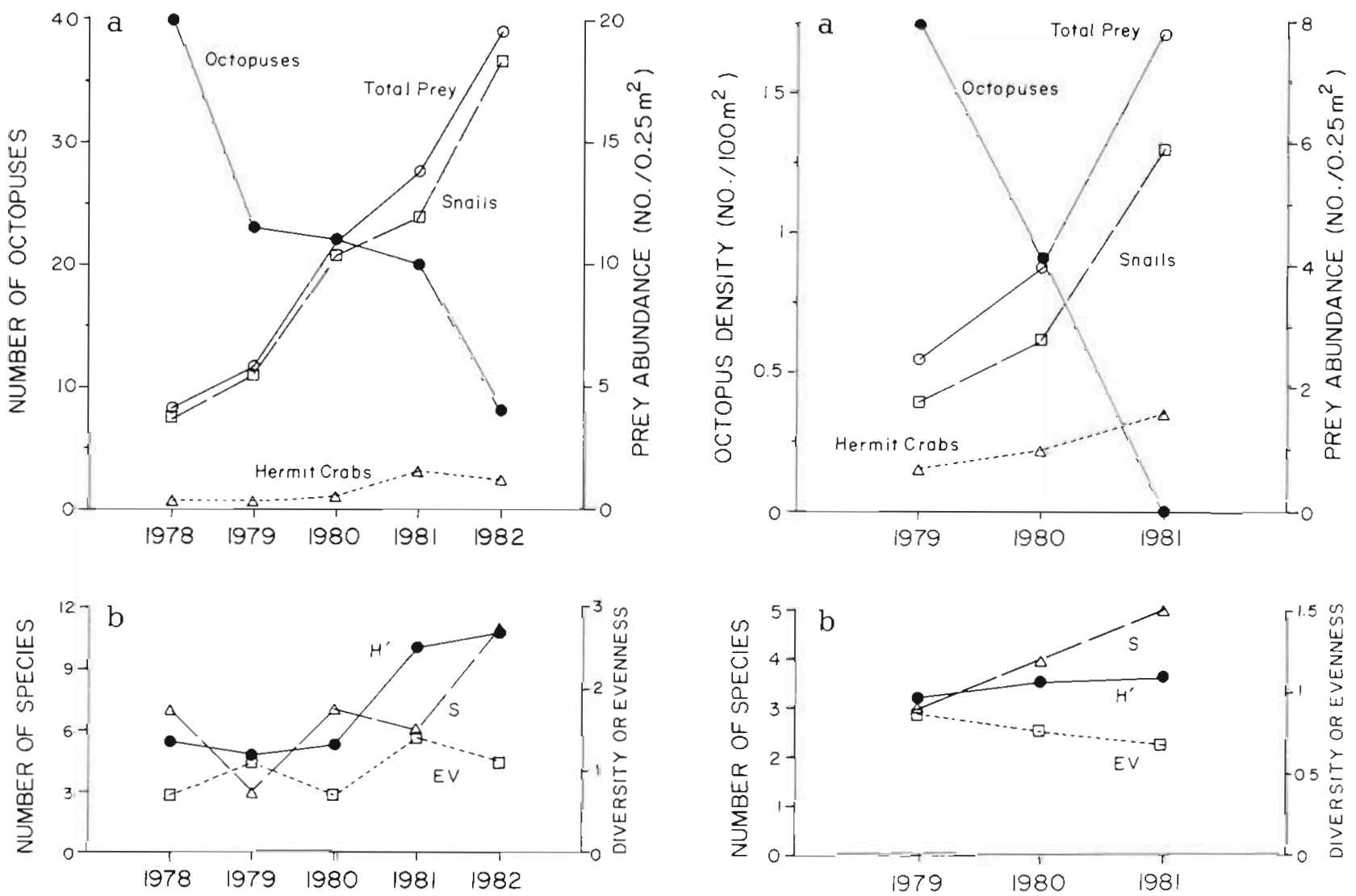

Fig. 2. Species abundance patterns at East Bird Rock between 1978 and 1982. (a) Abundances of octopuses and their prey. Octopus abundance is the total number of octopuses at the study site. Sedentary grazers, bivalves, and crabs and shrimps are not shown because they had consistently low densities. (b) Community relations. $\mathrm{S}=$ number of species; $\mathrm{H}^{\prime}=$ diversity; $\mathrm{EV}=$ evenness
Fig. 3. Species abundance patterns at West Bird Rock between 1979 and 1981. (a) Abundances of octopuses and their prey. Octopus abundance is the density estimated from an approximately $200 \mathrm{~m}^{2}$ sample area. Sedentary grazers, bivalves, and crabs and shrimps are not shown because they had consistently low densities. (b) Community relations 
period ( $3.7 \pm 0.8$ in 1978 to $18.4 \pm 1.4$ in 1982; Fig. 2). Hermit crabs also increased substantially $(0.4 \pm 0.1$ in 1978 to $1.2 \pm 0.2$ in 1982). Crabs and shrimps, bivalves and sedentary grazers were present in very low abundance throughout 1978 to 1982. In 1978, the densities. of sedentary grazers and bivalves were 0.1 and 0 ind $0.25 \mathrm{~m}^{-2}$, respectively; in all other years grazers and bivalves had 0 density until 1982, when the density of both groups was 0.2 ind $0.25 \mathrm{~m}^{-2}$. Crab and shrimp density was 0 in 1978 and 1979, 0.29 in 1981, and 0.10 ind $0.25 \mathrm{~m}^{-2}$ in 1982. The different responses of the prey groups are reflected in the significant interaction between prey group abundances and year in the ANOVA $(\mathrm{p}<0.001$, Table $3 \mathrm{~A})$.

There was no significant correlation between octopus density and the number of prey species ( $\mathrm{r}=$ $-0.44, \mathrm{n}=5)$, species diversity ( $\mathrm{r}=-0.68)$ or even- ness ( $r=-0.56$ ) (Fig. 2). However, the number of prey species, which varied from 3 to 10 , was highest in the year of lowest octopus abundance. Moreover, it is possible that the effects of octopus predation would only be apparent some years after the predation occurred. To evaluate this possibility I calculated correlations between octopus abundance and the community parameters in the following year. The correlations with number of taxa and species diversity were better ( $\mathrm{r}=$ -0.83 and $r=-0.71$, respectively, $n=4$ ), while the correlation with evenness was poorer $(\mathrm{r}=-0.03)$.

Although only covering $3 \mathrm{yr}$, the species abundance patterns at West Bird Rock are virtually identical to those at East Bird Rock (Table 3B). Between 1979 and 1981, octopus density decreased from 1.74 to 0 ind $100 \mathrm{~m}^{-2}$, while total prey density increased from $2.5 \pm 0.6$ to $7.8 \pm 1.3$ ind $0.25 \mathrm{~m}^{-2}$ (Fig. 3). Snails

Table 4. Densities of invertebrate predators and prey groups

\begin{tabular}{|c|c|c|c|c|c|c|c|c|c|c|c|}
\hline \multirow{2}{*}{$\begin{array}{l}\text { Study } \\
\text { site } \\
\text { number }\end{array}$} & \multicolumn{5}{|c|}{$\begin{array}{l}\text { Predator abundance } \\
\text { no. } 100 \mathrm{~m}^{-2}\end{array}$} & \multicolumn{5}{|c|}{$\begin{array}{l}\text { Prey group abundance } \\
\overline{\mathrm{X}} \text { (SE) no. } 0.25 \mathrm{~m}^{-2}\end{array}$} & \multirow[b]{2}{*}{$\begin{array}{l}\text { Sessile } \\
\text { prey }\end{array}$} \\
\hline & Octopus & Pisaster & Kelletia & Panulirus & Snails & $\begin{array}{l}\text { Sedentary } \\
\text { grazers }\end{array}$ & Bivalves & $\begin{array}{l}\text { Crusta- } \\
\text { ceans }\end{array}$ & $\begin{array}{l}\text { Hermit } \\
\text { crabs }\end{array}$ & $\begin{array}{l}\text { Verme- } \\
\text { tids }\end{array}$ & \\
\hline 1 & 0 & 0.33 & 2.33 & 0 & $\begin{array}{l}18.90 \\
(1.87)\end{array}$ & $\begin{array}{l}0.15 \\
(0.08)\end{array}$ & 0 & $\begin{array}{c}0.05 \\
(0.05)\end{array}$ & $\begin{array}{c}0.75 \\
(0.20)\end{array}$ & $\begin{array}{l}0.10 \\
(0.07)\end{array}$ & 0 \\
\hline 2 & 0 & 0 & 0 & 4.38 & $\begin{array}{c}4.85 \\
(0.95)\end{array}$ & 0 & 0 & $\begin{array}{c}1.09 \\
(0.42)\end{array}$ & $\begin{array}{c}0.55 \\
(0.17)\end{array}$ & $\begin{array}{l}34.10 \\
(5.05)\end{array}$ & $\begin{array}{c}0.15 \\
(0.11)\end{array}$ \\
\hline 3 & 0 & 1.88 & 0 & 1.88 & $\begin{array}{c}1.35 \\
(0.47)\end{array}$ & 0 & 0 & $\begin{array}{c}1.10 \\
(0.47)\end{array}$ & $\begin{array}{c}0.45 \\
(0.21)\end{array}$ & $\begin{array}{l}12.35 \\
(2.11)\end{array}$ & $\begin{array}{c}0.05 \\
(0.05)\end{array}$ \\
\hline 4 & 0 & 0.71 & 0.36 & 0.71 & $\begin{array}{c}6.90 \\
(1.86)\end{array}$ & $\begin{array}{c}0.25 \\
(0.16)\end{array}$ & 0 & $\begin{array}{c}0.65 \\
(0.47)\end{array}$ & $\begin{array}{l}1.70 \\
10.56\end{array}$ & $\begin{array}{c}4.15 \\
(1.03)\end{array}$ & 0 \\
\hline 5 & 0 & 0.71 & 0 & 7.14 & $\begin{array}{c}4.20 \\
(0.98)\end{array}$ & $\begin{array}{c}0.35 \\
(0.15)\end{array}$ & $\begin{array}{c}0.05 \\
(0.05)\end{array}$ & $\begin{array}{c}0.90 \\
(0.27)\end{array}$ & $\begin{array}{c}0.85 \\
(0.36)\end{array}$ & $\begin{array}{l}10.00 \\
(2.77)\end{array}$ & $\begin{array}{c}1.35 \\
(1.35)\end{array}$ \\
\hline 6 & 0 & 2.50 & 0 & 0.63 & $\begin{array}{c}7.25 \\
(1.70)\end{array}$ & $\begin{array}{c}0.05 \\
(0.05)\end{array}$ & 0 & $\begin{array}{c}0.30 \\
(0.18)\end{array}$ & $\begin{array}{c}0.40 \\
(0.21)\end{array}$ & $\begin{array}{c}8.40 \\
(2.03)\end{array}$ & $\begin{array}{c}0.30 \\
(0.30)\end{array}$ \\
\hline 7 & 0.31 & 1.25 & 0 & 0.63 & $\begin{array}{c}3.85 \\
(0.93)\end{array}$ & $\begin{array}{c}1.25 \\
(0.85)\end{array}$ & 0 & $\begin{array}{c}0.50 \\
(0.25)\end{array}$ & $\begin{array}{c}0.60 \\
(0.27)\end{array}$ & $\begin{array}{l}22.85 \\
(4.09)\end{array}$ & $\begin{array}{c}0.25 \\
(0.25)\end{array}$ \\
\hline 8 & 0.45 & 0 & 29.55 & 0.45 & $\begin{array}{l}8.00 \\
(2.04)\end{array}$ & $\begin{array}{c}0.20 \\
(0.12)\end{array}$ & $\begin{array}{l}0.05 \\
(0.05)\end{array}$ & $\begin{array}{c}1.60 \\
(0.65)\end{array}$ & $\begin{array}{c}0.45 \\
(0.31)\end{array}$ & $\begin{array}{c}4.95 \\
(2.93)\end{array}$ & $\begin{array}{c}0.75 \\
(0.30)\end{array}$ \\
\hline 9 & 0.63 & 0 & 3.75 & 0 & $\begin{array}{c}5.95 \\
(1.08)\end{array}$ & $\begin{array}{c}0.10 \\
(0.07)\end{array}$ & $\begin{array}{c}0.30 \\
(0.25)\end{array}$ & $\begin{array}{c}0.40 \\
(0.21)\end{array}$ & $\begin{array}{c}0.60 \\
(0.39)\end{array}$ & $\begin{array}{c}2.50 \\
(0.75)\end{array}$ & $\begin{array}{c}0.10 \\
(0.07)\end{array}$ \\
\hline 10 & 0.63 & 0 & 2.50 & 0 & $\begin{array}{c}7.55 \\
(1.72)\end{array}$ & $\begin{array}{c}0.05 \\
(0.05)\end{array}$ & 0 & 0 & $\begin{array}{c}1.85 \\
(0.93)\end{array}$ & $\begin{array}{l}18.30 \\
(4.45)\end{array}$ & 0 \\
\hline 11 & 0.83 & 0 & 0 & 0.63 & $\begin{array}{l}11.55 \\
(1.18)\end{array}$ & $\begin{array}{c}0.10 \\
(0.07)\end{array}$ & 0 & $\begin{array}{c}0.45 \\
(0.20)\end{array}$ & $\begin{array}{c}0.25 \\
(0.16)\end{array}$ & $\begin{array}{c}4.20 \\
(1.25)\end{array}$ & $\begin{array}{c}1.65 \\
(1.10)\end{array}$ \\
\hline 12 & 0.91 & 0.45 & 7.73 & 0 & $\begin{array}{r}2.75 \\
(0.60)\end{array}$ & $\begin{array}{c}0.25 \\
(0.25)\end{array}$ & 0 & 0 & $\begin{array}{c}0.95 \\
(0.28)\end{array}$ & $\begin{array}{l}12.75 \\
(1.57)\end{array}$ & 0 \\
\hline 13 & 1.11 & 0 & 1.67 & 1.67 & $\begin{array}{l}21.20 \\
(3.00)\end{array}$ & $\begin{array}{c}0.10 \\
(0.07)\end{array}$ & $\begin{array}{c}1.10 \\
(0.07)\end{array}$ & $\begin{array}{c}0.40 \\
(0.22)\end{array}$ & $\begin{array}{c}2.40 \\
(0.93)\end{array}$ & $\begin{array}{c}6.55 \\
(2.80)\end{array}$ & $\begin{array}{c}0.05 \\
(0.05)\end{array}$ \\
\hline 14 & 1.50 & 0.17 & 0.33 & 0 & $\begin{array}{l}10.40 \\
(0.77)\end{array}$ & 0 & 0 & $\begin{array}{c}0.05 \\
(0.05)\end{array}$ & $\begin{array}{c}0.55 \\
(0.27)\end{array}$ & $\begin{array}{c}1.20 \\
(0.40)\end{array}$ & 0 \\
\hline 15 & 1.67 & 2.78 & 0 & 0.56 & $\begin{array}{c}1.23 \\
(0.35)\end{array}$ & 0 & 0 & $\begin{array}{c}0.36 \\
(0.18)\end{array}$ & $\begin{array}{c}0.23 \\
(0.11)\end{array}$ & $\begin{array}{l}32.23 \\
(3.61)\end{array}$ & 0 \\
\hline
\end{tabular}


again showed the greatest change, increasing 3 -fold from $1.8 \pm 0.5$ to $5.9 \pm 1.2$ ind $0.25 \mathrm{~m}^{-2}$. Hermit crabs also increased every year, but the other 3 taxa occurred in low abundance during all $3 \mathrm{yr}$.

Community relations at West Bird Rock showed distinct trends (Fig. 3), but these changes must be viewed in light of the small sample size of $3 \mathrm{yr}$. Nonetheless, the number of prey taxa increased from 3 to 5 , yielding a significant negative correlation with octopus density $(r=-0.9996, p<0.05, n=3)$. Species diversity consistently increased with decreasing octopus density, while evenness consistently decreased.

\section{Species abundance relations}

Although I have focused primarily on the effect of octopus predation, in evaluating the patterns of species abundances I have included 3 other major invertebrate predators and their prey. The densities of the 4 predators and 7 prey groups at the 15 locations sampled are given in Table 4. (Abundances of the 27 individual species can be found in Ambrose 1982b). There are 11 significant correlations $(10.2 \%)$ between predator and prey species abundances (Table 5), as many as could occur from chance alone given the number of comparisons. All significant correlations are positive, and many are between predators and species not included in that predator's diet.

Because habitat structural variability among the study sites may have introduced enough 'noise' to mask true relations, partial correlations between predators and prey were calculated. In the partial correlations, the linear effects of the first 2 habitat principal components were removed. Nearly $20 \%$ of the resulting partial correlations are significant (Table 5), more than expected by chance. The major effect of holding habitat structure constant has been to indicate a number of significant negative correlations between Pisaster giganteus and the prey species. Most of these correlations are with species that are not included in the diet of $P$. giganteus. Chama arcana, however, may make up a large portion of $P$. giganteus diets (Nelson 1982).

Since there is considerable overlap in diet among the predator species, the abundances of a prey group

Table 5. Correlations between predators and prey species. Parentheses indicate negative values. In the partial correlations, the effects of habitat structure have been removed. " indicates $p<0.05: r>0.51$ for simple correlations, $r>0.58$ for partial correlations; ${ }^{\prime}$ indicates $\mathrm{p}<0.01: \mathrm{r}>0.64$ for simple correlations, $\mathrm{r}>0.71$ for partial correlations

\begin{tabular}{|c|c|c|c|c|c|c|c|c|}
\hline \multirow[t]{2}{*}{ Prey } & \multicolumn{4}{|c|}{ Simple correlations $(\mathrm{n}=15$ ) } & \multicolumn{4}{|c|}{ Partial correlations $(n=14)$} \\
\hline & Oct. & Pis. & Kel. & Pan. & Oct. & Pis. & Kel. & Pan. \\
\hline \multicolumn{9}{|l|}{ Tegula eiseni } \\
\hline \multicolumn{9}{|l|}{ Tegula aureotincta } \\
\hline \multicolumn{9}{|l|}{ Astraea undosa } \\
\hline \multicolumn{9}{|l|}{ Norrisia norrisi } \\
\hline Cypraea spadicea & & & $\cdots$ & & & $(\cdot)$ & $\cdots$ & \\
\hline Trivia solandri & & & & & $\left(0^{\circ}\right)$ & & & \\
\hline Abalone & & & & $\cdots$ & & & & - \\
\hline \multicolumn{9}{|l|}{ Limpets } \\
\hline Chitons & & & & & & $(")$ & & \\
\hline \multicolumn{9}{|l|}{ Lima hemphilli } \\
\hline Ventricolaria fordij & & & & & $\cdot$ & & & \\
\hline \multicolumn{9}{|l|}{ Paraxanthias taylori } \\
\hline \multicolumn{9}{|l|}{ Pugettia producta } \\
\hline \multicolumn{9}{|l|}{ Loxorhynchus spp. } \\
\hline Crab sp. A & & & $\cdots$ & & & $(\cdot)$ & $\cdots$ & \\
\hline Taliepus nuttallii & & & $\cdots$ & & & $(\because)$ & $\cdots$ & \\
\hline Unid. crabs & & & & $\cdot$ & & $(\cdot)$ & & $\cdot$ \\
\hline \multicolumn{9}{|l|}{ Betaeus spp. } \\
\hline Lysmata californica & & & $\cdots$ & & & $(\cdot)$ & $\cdots$ & \\
\hline \multicolumn{9}{|l|}{ Unid. shrimp } \\
\hline \multicolumn{9}{|l|}{ Hermit crabs } \\
\hline \multicolumn{9}{|l|}{ Serpulorbis squamigerus } \\
\hline Dendropoma & $\cdot$ & $\cdot$ & & & & & & \\
\hline Hinnites giganteus & & & $\cdots$ & & & ()$\left.^{\circ}\right)$ & $\cdots$ & \\
\hline \multicolumn{9}{|l|}{ Pododesmus cepio } \\
\hline Chama arcana & & & $\cdots$ & & & ()$\left.^{\circ}\right)$ & $\cdots$ & \\
\hline Megabalanus californicus & & & & $\cdots$ & & & & $\cdots$ \\
\hline
\end{tabular}


may be affected by more than one predator species at a time. I evaluated this 'diffuse predation' by examining the correlation between grouped predator abundances and their prey. Two predator groups were determined on the basis of diet. Octopus and lobsters were grouped together because they consume the same prey groups. Although diet information for Kelletia kelletii is sparse, Rosenthal (1971) reports that it may consume many of the same items as Pisaster giganteus. Accordingly, it was grouped with $P$. giganteus. Predator group abundances were determined by adding the abundances of the individual predators.

There were no significant correlations between the abundances of the 2 predator groups and their prey

Table 6. Correlations between predator groups and prey Predators are grouped by similar diets. The actual prey included in each predator's diet is printed in boldface. ${ }^{*}$ and - indicate a significant correlation at the 0.05 and 0.01 level. respectively

\begin{tabular}{|c|c|c|}
\hline Correlation & & r \\
\hline \multirow[t]{7}{*}{ Octopus \& Panulirus vs } & Snails & -0.16 \\
\hline & Sedentary grazers & -0.01 \\
\hline & Bivalves & -0.04 \\
\hline & Crustaceans & 0.17 \\
\hline & Hermit crabs & -0.01 \\
\hline & Vermetids & $0.66^{\circ}$ \\
\hline & Sessile Prey & 0.33 \\
\hline \multirow[t]{7}{*}{ Pisaster \& Kelletia vs } & Snails & -0.02 \\
\hline & Sedentary grazers & 0.02 \\
\hline & Bivalves & 0.11 \\
\hline & Crustaceans & $0.62^{\circ}$ \\
\hline & Hermit crabs & -0.19 \\
\hline & Vermetids & 0.32 \\
\hline & Sessile prey & -0.21 \\
\hline \multirow[t]{7}{*}{ Total predators vs } & Snails & -0.06 \\
\hline & Sedentary grazers & 0.01 \\
\hline & Bivalves & 0.10 \\
\hline & Crustaceans & $0.67^{\cdots}$ \\
\hline & Hermit crabs & -0.20 \\
\hline & Vermetids & 0.50 \\
\hline & Sessile prey & -0.13 \\
\hline
\end{tabular}

group abundances (Table 6). When all 4 predators are considered together, they are significantly positively correlated with crustacean abundances ( $\mathrm{r}=0.67$, $\mathrm{p}<0.01$; Table 6); no other correlations are significant.

It is possible that predators might have dissimilar effects on their preferred vs nonpreferred prey. The general prey preferences of Octopus bimaculatus and Pisaster giganteus are known: for $O$. bimaculatus the preferred prey are crustaceans, sedentary grazers, and bivalves (Ambrose 1984); for $P$. giganteus the preferred prey are bivalves, sessile prey, and sedentary grazers (Nelson 1982). There were no significant correlations between $O$. bimaculatus and $P$. giganteus abundances and either preferred or nonpreferred prey abundances loctopus vs preferred prey, $\mathrm{r}=-0.33$, vs nonpreferred prey, $\mathrm{r}=0.007 ; P$. giganteus vs preferred prey, $\mathrm{r}=$ 0.33 , vs nonpreferred prey, $\mathrm{r}=0.007$ ).

When the contribution of the habitat principal components is removed through partial correlations, there are 3 significant correlations between predator abundances and the measures of species richness and diversity of the prey community (Table 7). Pisaster giganteus is negatively correlated with both the number of species and the prey species diversity at a site, and Kelletia kelletii is positively correlated with the number of species. The 3 significant correlations observed out of 20 could be the result of statistical variation rather than reflecting real correlations, although the magnitude of the negative correlation with species richness suggests a real relation.

\section{DISCUSSION}

\section{Community structure}

A decrease in species diversity in response to predation pressure has been reported for marine (Sammarco et al. 1974, Day 1977, Virnstein 1977, Lubchenco 1978, Raffaelli 1979, Vance 1979, Holland et al. 1980, Wiltse 1980) and freshwater (Addicott 1974, Gilinsky 1984,

Table 7. Predator and prey community relations. In the partial correlations, the effects of habitat structure have been held constant. "and " indicate a significant correlation at the 0.05 and 0.01 level, respectively

\begin{tabular}{|c|c|c|c|c|c|c|c|c|}
\hline & \multicolumn{4}{|c|}{ Simple correlations } & \multicolumn{4}{|c|}{ Partial correlations } \\
\hline & Oct. & Pis. & Kel. & Pan. & Oct. & Pis. & Kel. & Pan. \\
\hline Species no. & -0.32 & -0.47 & $0.64^{\circ}$ & 0.22 & -0.31 & $-0.82 \cdots$ & $0.73^{*}$ & 0.12 \\
\hline Diversity & -0.02 & -0.42 & 0.49 & -0.12 & -0.02 & $-0.60^{\circ}$ & 0.48 & -0.11 \\
\hline Evenness & 0.13 & -0.32 & 0.32 & -0.24 & 0.11 & -0.42 & 0.31 & -0.19 \\
\hline Total abundance & 0.12 & 0.04 & -0.20 & 0.26 & 0.14 & 0.03 & -0.20 & 0.24 \\
\hline
\end{tabular}


see also Thorp \& Bergey 1981) communities. At Bird Rock, where the highest species richness and diversity occurred in the year of the lowest octopus abundance, octopus predation appears to decrease the number of species in the assemblage. Species richness, diversity and evenness of the prey assemblage were generally not correlated with predator densities at different locations at Catalina Island, except for the negative partial correlations between Pisaster giganteus abundances and species richness and diversity when habitat structure is held constant. In general, the relation between predation and species diversity suggests that these predators reduce, rather then increase, diversity.

In contrast, many studies have indicated that predation increases species diversity of rocky substrate marine communities (Paine 1966, Paine \& Vadas 1969, Dayton 1971, Porter 1972, Day 1977, Lubchenco 1978 Peterson 1979, Russ 1980). The specific community response to predation depends on how effectively the predator reduces species abundances, how selective it is, and the nature of the competitive relations among the prey. Octopus bimaculatus can be effective in reducing prey abundance, and is a selective predator (Ambrose 1984). However, competitive relations appear to be the principal factors determining how predation affects species richness in this assemblage. The 'prey' species include most of the conspicuous invertebrates on subtidal rocky reefs at Catalina; none of the excluded species, such as sea cucumbers or urchins, seem likely to be dominant competitors. The relations among the prey species are explored more fully elsewhere (Ambrose 1982b), with the results indicating the absence of a competitive dominant: even at low predator densities or high prey species abundances, no species has increased abundance at the expense of others. In the absence of one or a few competitive dominants, predation cannot increase species richness.

In all of the communities cited above for a positive effect of predation on species richness, the absence of predation results in dominance by a sessile species (sessile invertebrate or alga) that monopolizes a simple resource, space. Such simple dominance may be less likely to occur in an assemblage of motile species, for motility offers a dimension to the predator-prey relation not found with sessile prey. Motility may reduce the effectiveness of a predator; it may also add complexity to the competitive relations among species. For these reasons, predation on motile prey species may be less likely to enhance the diversity of those assemblages. Of course, motility does not guarantee that competitive exclusion will not occur, and predation has been reported to increase the number of coexisting zooplankton species in several freshwater communities (Hall et al. 1970, Zaret 1972, Neill 1975).

\section{Prey abundances}

Octopus predation accounts for an estimated 57 to $99 \%$ of the snail mortality at Santa Catalina Island, more than the combined effects of seastars and gastropods. Octopus bimaculatus may also be an important predator in the intertidal at Catalina, with $>90 \%$ of the shells of snails (Tegula funebralis and $T$. gallina) and abalone (Haliotis cracherodii) drilled (unpubl. data). Octopuses cause a similar proportion of the mortality of some species in other communities (Onuf 1.972, Fotheringham 1974, Ambrose \& Nelson 1983, Fawcett 1984). Moreover, the Isthmus Reef experiment indicates that, under those conditions, octopuses alone could effectively eliminate their prey in less than $100 \mathrm{~d}$. Predation this intense would seem to be incompatible with the persistence of prey populations. In fact, the pre-manipulation snail density at Isthmus Reef was practically zero.

The changes in species abundances over several years at Bird Rock suggest that octopuses can reduce the abundances of unmanipulated prey populations. The negative correlation between octopus and snail abundances is particularly compelling evidence because it involves a temporal sequence of prey abundances, all measured at the same place. Of course, year-to-year variation due to unknown factors cannot be eliminated. But the fact that independent observations at West Bird Rock and East Bird Rock revealed the same patterns makes it unlikely that these patterns are due simply to chance.

Bivalves, sedentary grazers, and crustaceans occurred at low densities at Bird Rock throughout this period. The minimal association between these prey groups and octopus abundance could be because (1) octopus predation does not affect these groups, (2) the abundances of these prey groups were depressed by octopus predation even during years of low octopus density, or (3) there has been insufficient time for these populations to respond to reduced octopus predation intensity. Crustaceans, bivalves, and sedentary grazers are highly preferred prey of Octopus bimaculatus, and octopuses forage preferentially for these prey (Ambrose 1984). Preferential predation would be consistent with the second explanation, so that even in years of low octopus abundance predation may be sufficiently intense to reduce the abundances of preferred prey.

From the inverse relations between octopus and prey abundances at Bird Rock over several years, I expected a negative correlation between predator and prey abundances measured at several different locations at one point in time. Negative correlations between predators and prey have been previously reported for the Catalina Island (Schmitt 1982) and other marine (Com- 
mito 1982, Mahoney \& Livingston 1982, Schroeter et al 1983, Fawcett 1984) and terrestrial (Lomolino 1984) communities. However, I found little evidence that prey abundances were negatively correlated with the abundances of their predators, either for simple correlations or partial correlations in which the effects of habitat structure were removed. These data suggest that, in the habitats studied here, predators do not influence the spatial structure of this prey assemblage.

Consideration of actual octopus densities suggests why there was no spatial association. The data indicating that octopuses reduce the abundances of their prey were collected under conditions of unusually high octopus densities. In 1978 the octopus density at East Bird Rock, estimated at 3 ind $100 \mathrm{~m}^{-2}$, was 1.4 times higher than that recorded in any other year over a 6 yr period, and 5 times higher than the density in 1982. During the lsthmus Reef experiment the octopus density was even higher: 4.0 to 6.7 octopuses $100 \mathrm{~m}^{-2}$. Unusually high octopus densities such as these would be more likely to result in a negative association between octopuses and their prey, whereas at normal densities octopuses may not reduce prey densities enough to disrupt the basic patterns of prey abundances that result from other processes, such as larval recruitment or influence of the physical environment. Thus octopuses at Santa Catalina Island may influence the spatial distribution of their prey when they are unusually abundant, but not at the densities normally encountered during this study.

Periodic increases in abundance have also been reported for other predators (Rees \& Lumbry 1954, Wiens 1977, Ayling 1981, Shachak et al. 1981, Kephart \& Arnold 1982). The occasionally high densities of predators may have profound effects on prey populations. For example, a 'plague' of octopuses in the English Channel virtually eliminated large crustaceans for a period (Rees \& Lumbry 1954), and an exceptional event of predation by migrating birds decimated desert snail populations in Israel, with long-term population consequences for one species (Shachak et al. 1981). The mortality rate of these desert snails $(30$ to $70 \%$ within $55 \mathrm{~d}$ ) was similar to that experienced by the marine snails during the Isthmus Reef experiment. If occasional years of high predation intensity are interspersed with longer periods of much reduced predation, there are several important ecological and evolutionary implications. Some species may experience periods of unusually low population sizes while predation intensity is high, and these periods are likely to be unpredictable and asynchronous among locations and predator species. This pattern of predation may influence the life history features of many of the organisms in this assemblage (Ayling 1981).

The relatively low intensity of predation that seems to be the norm for this temperate community contrasts sharply with the intensity reported for some tropical communities. Tropical communities have more types of predators and year-round foraging by all predators (Menge \& Lubchenco 1981). Most shelled molluscs at Catalina seem relatively immune to fish predation (pers. obs.), whereas fish in tropical communities effectively consume many shelled prey, and exposed benthic invertebrates are rare (Bertness et al. 1981, Menge \& Lubchenco 1981). Fast- and slow-moving predators severely restrict the distributions and abundances of both sessile and motile species in these tropical communities (Garrity \& Levings 1981, Menge \& Lubchenco 1981). Predation on subtidal invertebrates seems to be much less intense at Santa Catalina Island.

Acknowledgements. I thank J. Benson, F. G. Hochberg, J. Morin, R. Schmitt, and R. Vance for advice during this research, K. Gellenbeck, J. Griffiths, and A. Harrington for diving assistance, and J. Benson, $J$. Coyer, and J. Pearse for comments on the manuscript. Special thanks to Bobette Nelson for advice, diving, comments, and much more. The University of California and Lerner Fund for Marine Research provided financial support. Computer funds were provided by the Department of Biology, UCLA, and the Department of Biological Sciences, Simon Fraser University. This is contribution No. 89 from the Catalina Marine Science Center.

\section{LITERATURE CITED}

Addicott, J. F. (1974). Predation and prey community structure: An experimental study of the effect of mosquito larvae on the protozoan communities of pitcher plants. Ecology 55: 475-492

Ambrose, R. F. (1982a). Shelter utilization by the molluscan cephalopod Octopus bimaculatus. Mar. Ecol. Prog. Ser. 7: $67-73$

Ambrose, R. F. (1982b). Octopus predation and community structure of subtidal rocky reefs at Santa Catalina Island, California. Dissertation, Univ. of California, Los Angeles

Ambrose, R. F. (1984). Food preferences, prey availability, and the diet of Octopus bimaculatus Verrill. J. exp. mar. Biol. Ecol. 74: 29-44

Ambrose, R. F., Nelson, B. V. (1982). Inhibition of giant kelp recruitment by an introduced brown alga. Botanica Mar. 25: 265-267

Ambrose, R. F., Nelson, B. V. (1983). Predation by Octopus vulgaris in the Mediterranean. P. S. Z. N. I: Mar. Ecol. 4: $251-261$

Ansell, A. D. (1969). Defensive adaptations to predation in the Mollusca. J. mar biol. Ass. India 3: 487-512

Ayling, A. M. (1981). The role of biological disturbance in temperate subtidal encrusting communities. Ecology 62: $830-847$

Bernstein, B. B., Williams, B. E., Mann, K. H. (1981). The role of behavioral responses to predators in modifying urchins' (Strongylocentrotus droebachiensis) destructive grazing and seasonal foraging patterns. Mar. Biol. 63: 39-49

Bertness, M. D., Garnity, S. D., Levings, S. C. (1981). Predation pressure and gastropod foraging: a temperate-tropical comparison. Evolution 35: 995-1007 
Commito, J. A. (1982). Importance of predation by infaunal polychaetes in controlling the structure of a soft-bottom community in Maine, USA. Mar Biol. 68: 77-81

Connell, J. H. (19707. A predator-prey system in the marine intertidal region. I. Balanus glandula and several predatory species of Thais. Ecol. Monogr. 40:49-78

Day, R. W. (1977). Two contrasting effects of predation on species richness in coral reef habitats. Mar. Biol. 44: 1-5

Dayton, P. K. (1971). Competition, disturbance, and community organization: the provision and subsequent utilization of space in a rocky intertidal community. Ecol. Monogr. 41: 351-389

Dixon, W. J., Brown, M. B. (1979). BMDP-79 Biomedical computer programs. University of California Press, Los Angeles

Duggins, D. O. (1980). Kelp beds and sea otters: an experimental approach. Ecology 61: 447-453

Fawcett, M. H. (1984). Local and latitudinal variation in predation on an herbivorous marine snail. Ecology 65: $1214-1230$

Feder, H. M. (1963). Gastropod defensive responses and their effectiveness in reducing predation by seastars. Ecology 44: $505-512$

Fotheringham, N. (1974). Trophic complexity in a littoral boulderfield. Limnol Oceanogr. 19: 84-91

Garrity, S. D., Levings, S. C. (1981). A predator-prey interaction between two physically and biologically constrained tropical rocky shore gastropods: direct, indirect and community effects. Ecol. Monogr. 51: 267-286

Gilinsky, E. (1984). The role of fish predation and spatial heterogeneity in determining benthic community structure. Ecology 65: 455-468

Hall, D. J., Cooper, W. E., Werner, E. E. (1970). An experimental approach to the production dynamics and structure of freshwater animal communities. Limnol. Oceanogr. 15: $829-928$

Harper, J. L. (1969). The role of predation in vegetational diversity. Brookhaven Symp. Biol. 22: 48-62

Hines, A. H., Pearse, J. S. (1982). Abalone, shells, and sea otters: dynamics of prey populations in central California. Ecology 63: 1547-1560

Hochberg, F. G., Fields, W. G. (1980). Cephalopods: the squids and octopuses, Chapter 17. In: Morris, R., Abbott, D., Haderlie, E. (ed.) Intertidal invertebrates of California. Stanford Univ. Press, Stanford, p. 429-444

Holland, A. F., Mountford, N. K., Hiegal, M. H., Kaumeyer, K. R., Mihursky, J. A. (1980). Influence of predation of infaunal abundance in Upper Chesapeake Bay, USA. Mar Biol. 57: 221-235

Kephart, D. G., Amold, S. J. (1982). Garter snake diets in a fluctuating environment: a seven-year study. Ecology 63 $1232-1236$

Lomolino, M. V. (1984). Immigrant selection, predation, and the distributions of Microtus pennsylvanicus and Blarina brevicauda on islands. Am. Nat. 123: 468-483

Lubchenco, J. (1978). Plant species diversity in a marine intertidal community: Importance of herbivore food preference and algal competitive abilities. Am. Nat. 112 23-39

Mahoney, B. M. S., Livingston, R. J. (1982). Seasonal fluctuations of benthic macrofauna in the Apalachicola Estuary, Florida, USA: The role of predation. Mar. Biol. 69 : $207-213$

Markowitz, D. V. (1980). Predator influence on shore-level size gradients in Tegula funebralis (A. Adams). J. exp. mar. Biol. Ecol. 45: 1-13

McKillup, S. C. (1982). The selective advantage of avoidance of the predatory whelk Lepsiella vinosa (Lamarck) by Littorina unifasciata (Philippi). J. exp. mar. Biol. Ecol. 63: $59-66$

Menge, B. A., Lubchenco, J. (1981). Community organization in temperate and tropical rocky intertidal habitats: prey refuges in relation to consumer pressure gradients. Ecol. Monogr. 51: 429-450

Muntz, L., Ebeling, F. J., Kitching, J. A. (1965). The ecology of Lough Ine XIV. Predatory activity of large crabs. J. Anim. Ecol. 34: 315-329

Neill, W. E. (1975). Experimental studies of microcrustacean competition, community composition and efficiency of resource utilization. Ecology 56: 808-826

Nelson, B. V (1982). The adaptive significance of aggregation and hermaphroditism in the sessile gastropod Serpulorbis squamigerus (Mollusca: Gastropoda). Dissertation, Univ. of California, Los Angeles

Nelson, B. V., Vance, R. R. (1979). Diel foraging patterns of the sea urchin Centrostephanus coronatus as a predatoravoidance strategy. Mar. Biol. 51: 251-258

Onuf, C. P. (1972). Aspects of the population biology of the intertidal snail Olivella biplicata: distribution, nutrition and effects of natural enemies. Dissertation, Univ. of California, Santa Barbara

Paine, R. T. (1966). Food web complexity and species diversity. Am. Nat. 100: 65-75

Paine, R. T. (1969). The Pisaster-Tegula interaction: prey patches, predator food preference, and intertidal community structure. Ecology 50: 950-961

Paine, R. T., Vadas, R. L. (1969). The effects of grazing by sea urchins, Strongylocentrotus spp., on benthic algal populations. Limnol. Oceanogr. 14: 710-719

Peterson, C. H. (1979). The importance of predation and competition in organizing the intertidal epifaunal communities of Barnegat Inlet, New Jersey. Oecologia (Berl.) 39: $1-24$

Pielou, E. C. (1977). Mathematical ecology. J. Wiley and Sons, New York

Pilson, M. E. Q., Taylor, P. B. (1961). Hole drilling by octopus. Science 134: 1366-1368

Porter, J. W. (1972). Predation by Acanthaster and its effect on coral species diversity. Am. Nat. 106: 487-492

Raffaelli, D. (1979). The grazer-algae interaction in the intertidal zone on New Zealand rocky shores. J. exp. mar. Biol. Ecol. 38: 81-100

Rees, W. J., Lumbry, J. H. (1954). The abundance of Octopus in the English Channel. J. mar. biol. Assoc. U. K. 33: $515-536$

Rohlf, F. J., Sokal, R. R. (1969). Statistical tables. W. H. Freeman and Co., San Francisco

Rosenthal, R. J. (1971). Trophic interaction between the sea star Pisaster giganteus and the gastropod Kelletia kelletii. Fish. Bull. U. S. 69: 669-679

Russ, G. R. (1980). Effects of predation by fishes, competition and structural complexity of the substratum on the establishment of a marine epifaunal community. J. exp. mar Biol. Ecol 42: 55-69

Sammarco, P. W., Levinton, J. S., Ogden, J. C. (1974). Grazing and control of coral reef community structure by Diadema antillarum Philippi (Echinodermata: Echinoidea): a preliminary study. J. mar. Res. 32: 47-53

Schmitt, R. J (1981). Contrasting anti-predator defenses of sympatric marine gastropods (Family Trochidae). J. exp. mar. Biol. Ecol. 54: 251-263

Schmitt, R. J. (1982). Consequences of dissimilar defenses against predation in a subtidal marine community. Ecology 63: $1588-1601$ 
Schmitt, R. J., Osenberg, C. W., Bercovitch, M. G. (1983). Mechanisms and consequences of shell fouling in the kelp snail, Norrisia norrisi (Sowerby) (Trochidae): Indirect effects of octopus drilling. J. exp. mar. Biol. Ecol. 69: $267-281$

Schroeter, S. C., Dixon, J., Kastendiek, J. (1983). Effects of the starfish Patiria miniata on the distribution of the sea urchin Lytechinus anamesus in a southern California kelp forest. Oecologia (Berl.) 56: 141-147

Shachak, M., Safriel, U. N., Hunum, R. (1981). An exceptional event of predation on desert snails by migratory thrushes in the Negev Desert, Israel. Ecology 62: 1441-1449

Thorp, J. H., Bergey, E. A. (1981). Field experiments on responses of a freshwater, benthic macroinvertebrate community to vertebrate predators. Ecology 62: 365-375

Tribble, G. W. (1981). Reef-based herbivores and the distribution of two seagrasses (Syringodium filiforme and Thalassia testudinum) in the San Blas Islands (Western Caribbean). Mar. Biol. 65: 277-281
Vance, R. R. (1979). Effects of grazing by the sea urchin, Centrostephanus coronatus, on prey community composition. Ecology 60: 537-546

Virnstein, R. W. (1977). The importance of predation by crabs and fishes on benthic infauna in Chesapeake Bay. Ecology 58: 1199-1217

Wells, R. A. (1980). Activity pattern as a mechanism of predator avoidance in two species of acmaeid limpet. J. exp. mar. Biol. Ecol. 48: 151-168

Wiens, J.A. (1977). On competition and variable environments. Am. Scient. 65: 590-597

Wiltse, W. I. (1980). Effects of Polinices duplicatus (Gastropoda: Naticidae) on infaunal community structure at Barnstable Harbor, Massachusetts, USA. Mar. Biol. 56: 301-310

Zaret, T. M. (1972). Predator-prey interaction in a tropical lacustrine ecosystem. Ecology 53: 248-257

This article was presented by Dr. K. E. Hoagland; it was accepted for printing on February 12, 1985 